\title{
Histone H3.1
}

National Cancer Institute

\section{Source}

National Cancer Institute. Histone H3.1. NCI Thesaurus. Code C101734.

Histone H3.1 (136 aa, $15 \mathrm{kDa}$ ) is encoded by the human $\mathrm{H} 3 \mathrm{C} 1, \mathrm{H} 3 \mathrm{C} 2, \mathrm{H} 3 \mathrm{C} 3, \mathrm{H} 3 \mathrm{C} 4$, $\mathrm{H} 3 \mathrm{C} 6, \mathrm{H} 3 \mathrm{C} 7, \mathrm{H} 3 \mathrm{C} 8, \mathrm{H} 3 \mathrm{C} 10, \mathrm{H} 3 \mathrm{C} 11$ and $\mathrm{H} 3 \mathrm{C} 12$ genes. This protein plays a role in the formation of chromatin structures. 